\title{
Improvement of black cotton soil with cattle bone powder
}

\author{
Iorliam, A. Y., Obam, S. O. and Owinizi, S. A.
}

Department of Civil Engineering, University of Agriculture, Makurdi, Nigeria. amosyalas2007@yahoo.com,ogahobam@yahoo.com and owinizi@yahoo.com

\begin{abstract}
Laboratory tests were conducted on black cotton soil (BCS) treated with cattle bone powder (CBP) in incremental order of $2 \%$ up to $10 \%$ of dry weight of soil sample, to ascertain its suitability for use as flexible pavement material. Classification, free swell, compaction, California bearing ratio (CBR) and unconfined compressive strength (UCS) tests, were conducted on BCS samples treated with CBP. Results of the tests showed that, BCS is an A-7-6 and CL respectively using the American Association of State Highway and Transport Officials (AASHTO) and unified soil classification system (USCS) respectively. The plasticity index (PI) and free swell of BCS reduced from $29.3 \%$ and $48 \%$ to $17.8 \%$ and $36 \%$ respectively. The maximum dry density reduced from $1.59 \mathrm{Mg} / \mathrm{m}^{3}$ to $1.40 \mathrm{Mg} / \mathrm{m}^{3}$ at $10 \%$ CBP. The reduction in the values of $\mathrm{PI}$ and free swell are indication of improvement in the swelling property of BCS. At $10 \%$ CBP content, maximum unconfined compressive strength (UCS) results values of $367 \mathrm{kN} / \mathrm{m}^{2}, 670$ $\mathrm{kN} / \mathrm{m}^{2}$ and $1031 \mathrm{kN} / \mathrm{m}^{2}$ were obtained at 7,14 and 28 days respectively.

The improvements in some of the geotechnical properties of BCS observed were not adequate enough for its use in road work. However, CBP can be used as a modifier, in the stabilization of BCS with cement or other additives.
\end{abstract}

Key words: Black cotton soil, cattle bone powder, California bearing ratio, unconfined compressive strength.

\section{INTRODUCTION}

The unsuitability of untreated BCS in road work is of great concern to the Civil Engineer. BCS is a typical example of expansive soils formed from the weathering of shaly and clayey sediments of basalts igneous rocks. It is predominantly composed of montmorillonite clay mineral which is characterized by large volume change with changes in moisture condition (NBRRI, 1983; Murthy, 2008). This volumetric problem is reflected in failure of roads and building constructed on areas where these soils are found.

In Nigeria, BCS occupy an estimated area of 104,000 $\mathrm{km}^{2}$ and are typically found in the North Eastern part of Nigeria such as Borno, Gombe, Adamawa, Yobe and Taraba States. This volumetric problem is well pronounced at Deba in Yamaltu/Deba Local Government Area (LGA) of Gombe State, as evident in cracks on buildings and roads within the town (see Plates 1 \& 2). Due to increasing shortage of good construction materials within localities where problem soils are encountered, avoiding or by-passing them is difficult, thus, necessitating the improvement of unsuitable natural soils for use in engineering work at economic cost. The use of CBP stems from the large quantity of cattle bones readily available in various abattoirs that litters the cities and villages in Nigeria and the attention gained world wide by the use of waste products in soil improvement owing to increasing cost of waste disposal and environmental constraints.

Various industrial and agricultural waste have been used in soil improvement such as cement kiln dust, blast furnace slag, rice husk ash, groundnut shell ash, sugar cane bagasse etc (Iorliam et al., 2012; Osinubi and Eberemu, 2005; Okafor and Okonkwo, 2009; Oriola and Moses, 2010; Madjo and Riskowiski, 2004).

Problem soil can also be improved with Cow Bone powder owing to its high content of $\mathrm{CaO}$, an aspect which has not received attention before. Few studies are recorded on the use of CBP in civil engineering. For example, Aribisala and Bamisaye (2006) have reported successful viability of bone powder in partial replacement of cement in concrete. Waste Cow bone powder is also reported to be capable of remediation of lead $\left(\mathrm{Pb}^{2+}\right)$ contaminated media owing to its effective adsorption mechanism (Cha et al., 2011). 
Am. J. Sci. Ind. Res., 2012, 3(3): 175-180

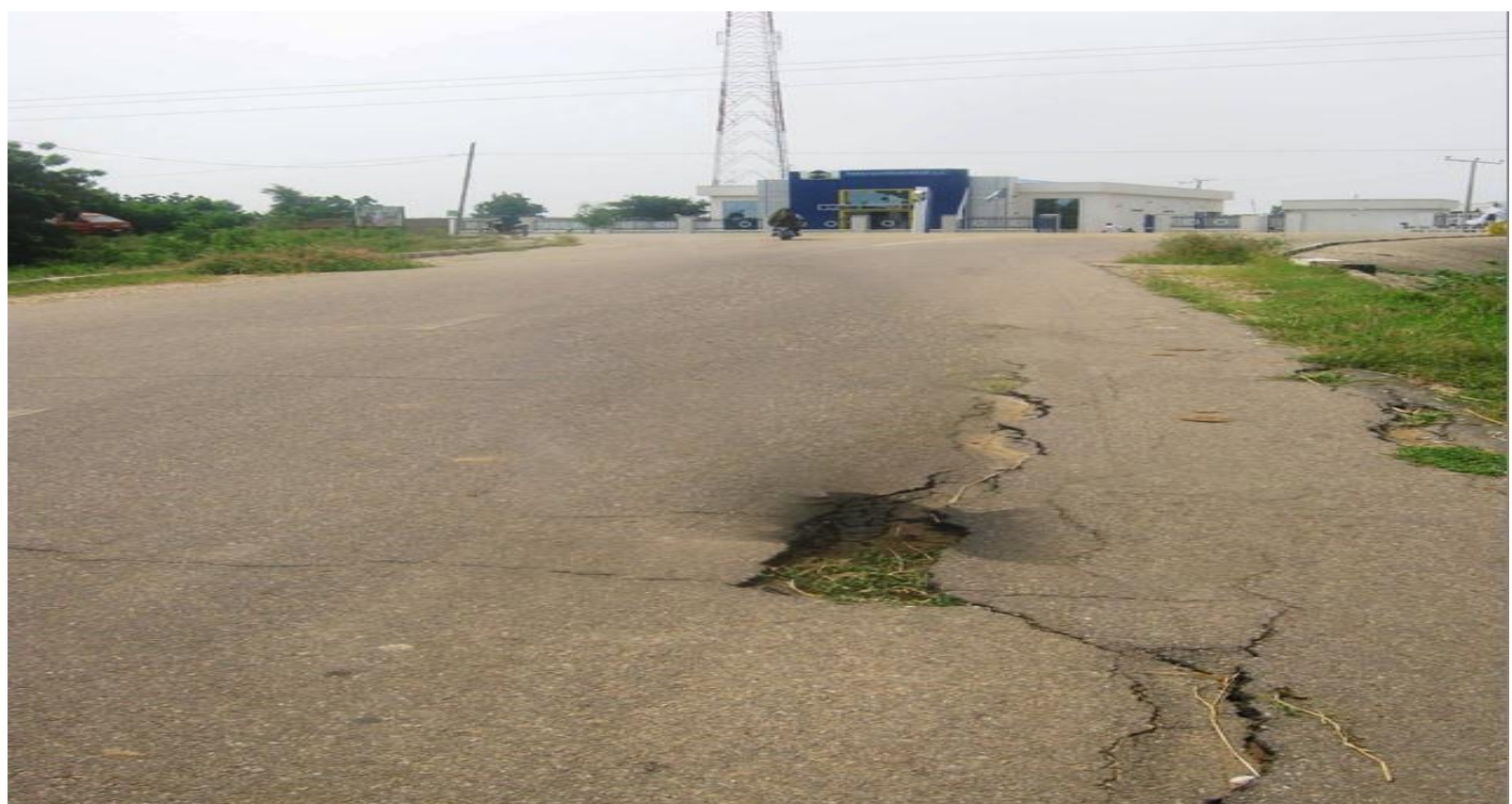

Plate 1. Failed Portion of Highway, close to Intercontinental Bank in Deba, Yamaltu/Deba LGA, Gombe State.

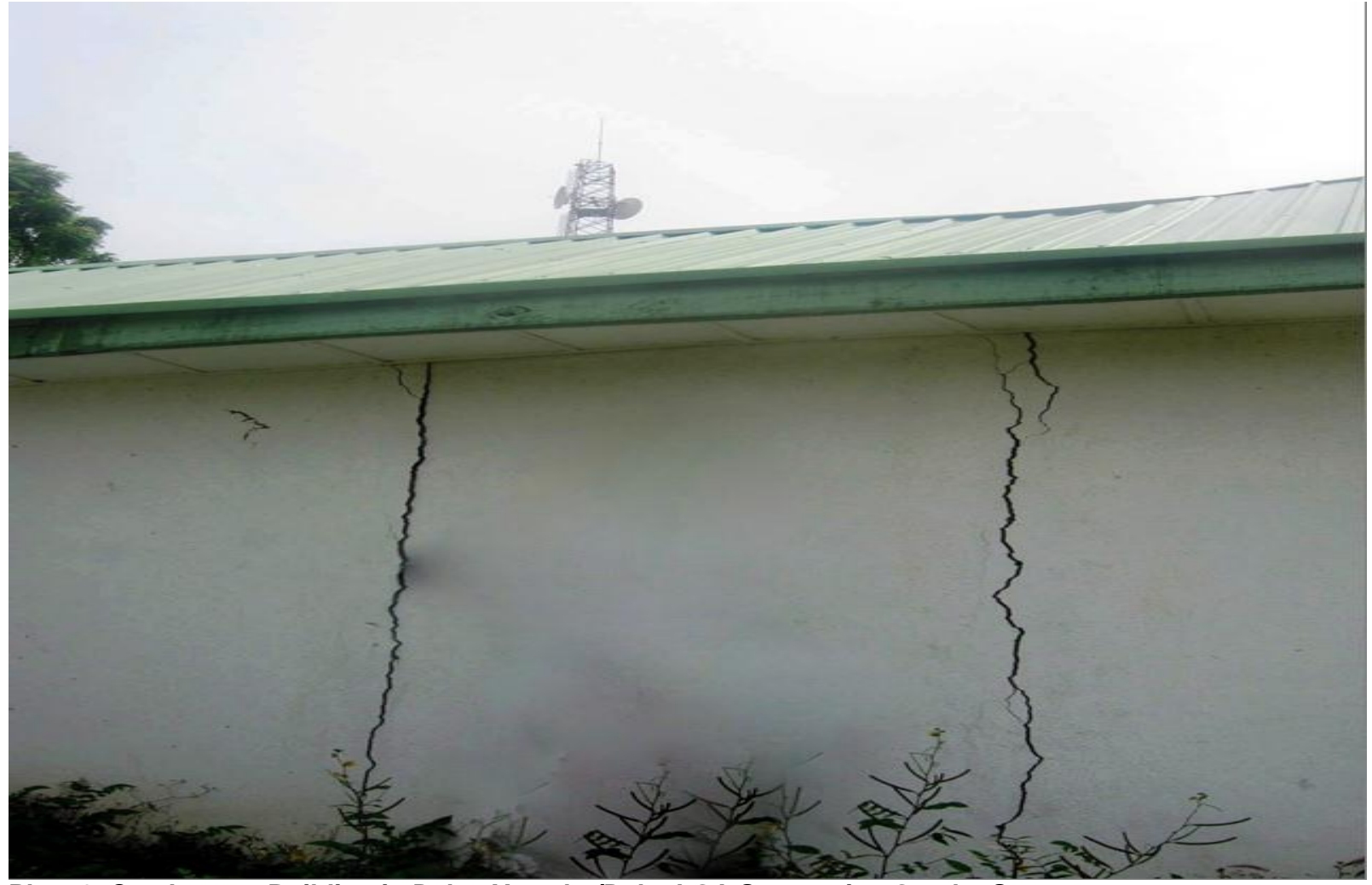

Plate 2. Cracks on a Building in Deba, Yamaltu/Deba LGA Secretariat, Gombe State. 
However, a study on the use of CBP in improvement of problem soil is rare. This has made this study very important. The aim of the study is to investigate the improvement in the geotechnical properties of BCS treated with CBP for its suitability for use as road building material.

Geology of the study area: Gombe formation is the main outcrop in the study area. It is a sequence of estuarine and deltaic sedimentation deposited towards the end of the Cretaceous (Maestrichtian) period (Kogbe, 1989). Carter et al. (1963) described Gombe formation to consist of three (3) sections namely, the upper, middle and lower sections. The lower beds are characterized by mudstones and ironstones. The latter vary from a few centimeters to $2 \mathrm{~m}$ in thickness. The middle part of the formation is composed of well-bedded sandstones and siltstones, while the upper bed consists of cross-bedded sandstones. The beds have been dated by palynological methods as Upper Maestrichtian to Paleocene. Gombe formation overlies the Fika shales of the Pindiga formation. Pindiga formation is marine shales of the Upper Turonian to Senonian age. The Fika shales consist of blue-black shales, occasionally gypsiferous with thin limestones intercalations fish and reptile remains have been obtained and these suggest a Turonian to Maestrichtian age (Carter et al., 1963). Finka shale lies on Yolde Formation which conformably overlies the massive coarse sandstones of the Bima Formation (Albian-Cenomanian): the oldest, most extensive and thickest of the Cretaceous sedimentary Formations in northeastern Nigeria. The Bima Formation rests directly on the Precambrian basement complex. The basement complex includes all the pre-Mesozoic rocks and is thus the oldest formation of the Nigerian stratigraphic series (Carter et al., 1963).

\section{MATERIALS AND METHODS}

The soil used in the study was BCS obtained from a burrowed pit $5 \mathrm{~m}$ away from centre line of DebaGombe township road, $100 \mathrm{~m}$ from Yamaltu/Deba local government secretariat, Deba, Gombe State, Nigeria. It lies between latitude $10^{\circ} 13^{\prime}$ and $10^{\circ} 2^{\prime}$ North and longitude $11^{\circ} 23^{\prime}$ and $11.383^{\circ}$ East, on the geographical map of Nigeria (http://en.wikipedia.org., 2011). CBP was obtained from Cattle bones from North-Bank market, Makurdi, Nigeria. The cattle bones were thoroughly cleaned and sun-dried to reduce its oil content before it was incinerated in a furnace at a temperature of $900^{\circ} \mathrm{C}$ at the Metallurgy laboratory, University of Agriculture Makurdi (See
Plate 3). Afterwards, the bones were allowed to cool and later ground in a hammer mill to fine powder.

Laboratory tests were performed on the sample in accordance with BS 1377 (1990) for the natural BCS and BS 1924 (1990) for BCS treated with CBP. The tests performed on the soil with CBP include, Atterberg limits, compaction, free swell, UCS and CBR tests. The CBR tests were conducted in accordance with the Nigerian General Specification (1997) which stipulates that specimens be cured in the dry for six days and then soaked for 24 hours before testing. Compaction was carried out at the energy level of the BS light compaction only; because this is easily achieved in the field. The resistance to loss in strength was determined as a ratio of the UCS of specimens cured for 7 days under controlled conditions, which were subsequently immersed in water for another 7 days to the UCS of specimens cured for 14 days.

$X$-ray fluorescence analysis was carried out on the CBP, and BCS samples, using Philips PW 1450/20 spectrometer to aid in the identification of oxides composition

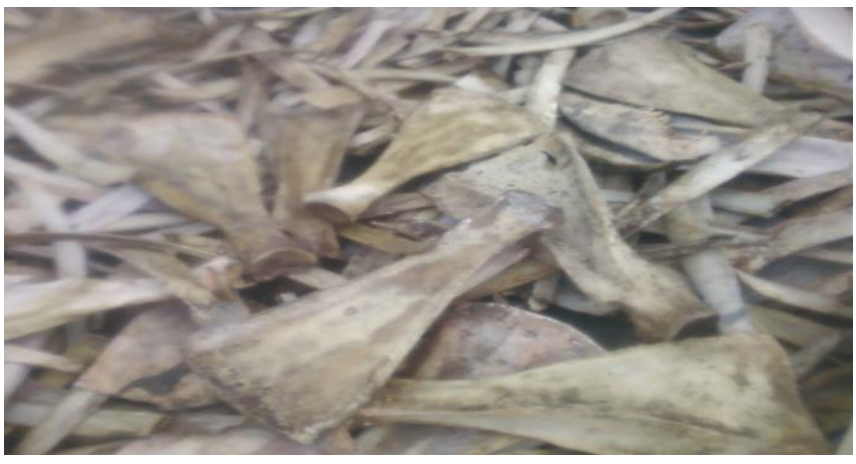

Plate 3. Sample of Cattle Bone

\section{RESULTS AND DISCUSSION}

Index Properties: The geotechnical index properties of natural BCS before the addition of CBP, is as summarized in Table 1 . The soil is an $A-7-6$ soil using the AASHTO classification system, low plasticity clay (CL) using the USCS (ASTM, 1992) and high swell potential soil according to NBRRI (1983) classification. The tests results showed that the natural soil was not suitable for use as sub-base or base course material and even requires a modified layer above it as a subgrade soil. The oxide composition obtained from the chemical analysis of CBP and BCS is summarized in Table 2. 
Am. J. Sci. Ind. Res., 2012, 3(3): 175-180

Effect of CBP on Consistency Limits and Swelling Property of BCS: Atterberg limits indices and free swell variation with CBP content is shown in Figures 1 and 2 respectively. Plastic limit increased from 27.5 to $29 \%$ with increased CBP content from 0 to $10 \%$, while the liquid limit, plasticity index (PI) and linear shrinkage (LS) decreased from 56.8, 29.3 and 15.7 $\%$ to $46.8,17.8$ and $12.1 \%$ respectively, with increased CBP content from 0 to $10 \%$. Similarly, the free swell decreased from $48 \%$ at $0 \%$ CBP content to $36 \%$ at $10 \%$ CBP content. Soil treated with $10 \%$ CBP produced least free swell, a reduction of $25 \%$. The reduction in PI from 29.3 to $17.8 \%$, produced significant improvement in the swelling potential from high to medium (Murthy, 2008). This is primarily due to the supply of more silica, alumina and calcium ion with increased CBP content.

Table 1: Results of Tests on Natural Black Cotton Soil.

\begin{tabular}{|l|c|}
\hline \multicolumn{1}{|c|}{ Property } & Quantity \\
\hline Percentage Passing BS Sieve No & 80 \\
$200 \%$ & 50.3 \\
Liquid Limit, \% & 26.1 \\
Plastic Limit, \% & 24.2 \\
Plasticity Index, \% & 14.3 \\
Linear Shrinkage, \% & $\mathrm{A}-7-6$ \\
AASHTO Classification & $\mathrm{CL}$ \\
USCS Classification & 1.59 \\
Maximum Dry Density, Mg/m ${ }^{3}$ & 18.6 \\
Optimum Moisture Content, \% & 182 \\
Unconfined Compressive Strength & 2 \\
kN/m ${ }^{2}$ & 7.2 \\
California bearing ration, \% (after 24 & 48 \\
hrs soaking) & High swell potential \\
pH & 2.78 \\
Free Swell, \% & Dark grey \\
NBRRI classification & 20.2 \\
Specific gravity & 2 \\
Colour & 20 \\
Natural moisture content (\%) & 38 \\
Gravel content (\%) & 40 \\
Sand content (\%) & \\
Silt content (\%) & \\
Clay content (\%) & \\
\hline
\end{tabular}

Table 2: Oxide Composition of CBP and BCS used.

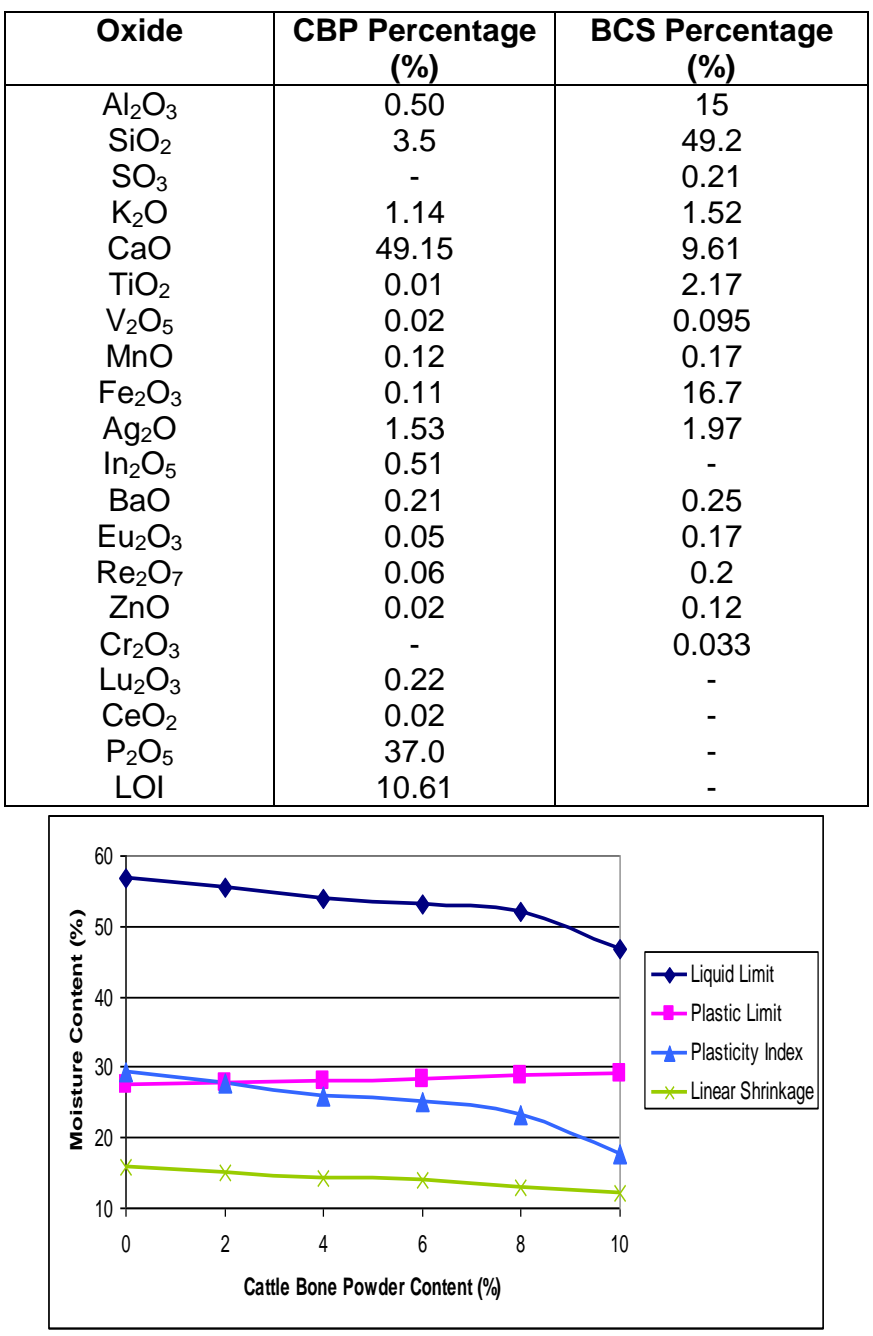

Fig 1. Variation of Atterberg limits indices with CBP content.

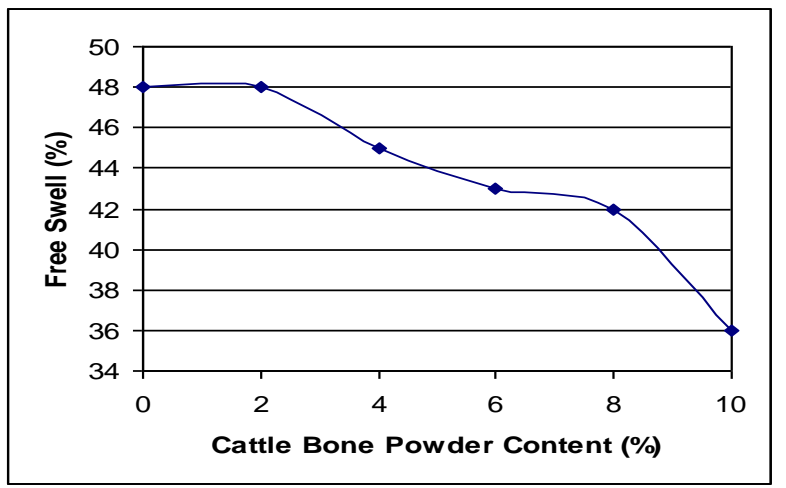

Fig 2: Variation of swelling properties of Black Cotton Soil with Cattle Bone Powder. 
Effect of CBP on Compaction Characteristics of BCS: The variation of the maximum dry density (MDD) and optimum moisture content (OMC) of BCS with CBP content is shown in Figure 3. The MDD and OMC (B.S light compaction) of BCS was substantially increased from $1.41 \mathrm{Mg} / \mathrm{m}^{3}$ and $18.0 \%$ at $0 \% \mathrm{CBP}$ content to $1.66 \mathrm{Mg} / \mathrm{m}^{3}$ and $21.2 \%$ at $10 \%$ CBP content respectively. The increase in the MDD is due to the flocculation and agglomeration leading to volumetric decrease in density and is in agreement with Medubi (1998). While the increasing OMC with increasing CBP content is as a result of extra water required for the pozzolanic reactions and is in agreement with Joel and Agbede (2008).

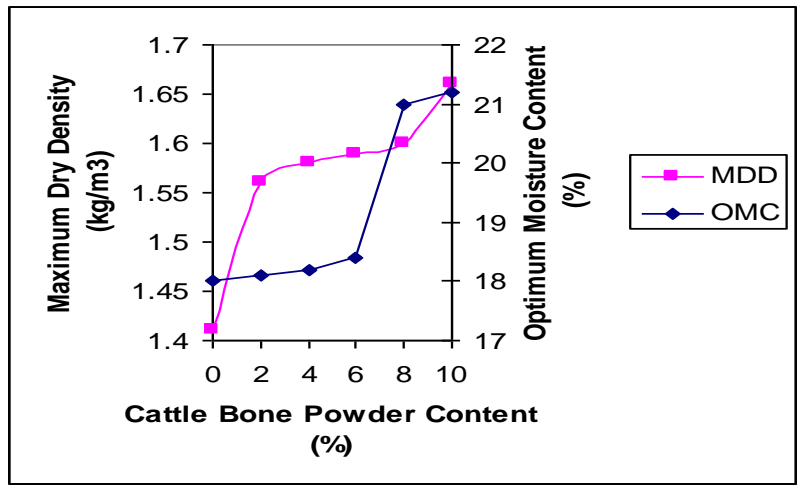

Fige 3. Variation of maximum dry density of Black Cotton Soil with Cattle Bone Powder.

Effect of CBP on UCS, CBR and Durability: Figure 4 shows the variation of unconfined compressive strength with CBP contents for 7, 14 and 28 days curing. The samples were compacted to their maximum dry densities at the corresponding moisture contents, extruded from mould and waxed cured for the different 7,14 and 28 days before subjecting them to test. The results indicated a proportional increase in strength with CBP content respectively. The peak UCS strength value at $10 \%$ CBP content corresponds to $367.12 \mathrm{kN} / \mathrm{m}^{2}, 670.10 \mathrm{kN} / \mathrm{m}^{2}$ and $1031.10 \mathrm{kN} / \mathrm{m}^{2}$ for 7,14 and 28 days respectively. The peak 7 day UCS value of $367.12 \mathrm{kN} / \mathrm{m}^{2}$ at $10 \%$ CBP content fell short of $1710 \mathrm{kN} / \mathrm{m}^{2}$ specified by TRRL (1977) as criterion for adequate stabilization using OPC. However, CBP shows progressive strength development with longer curing periods from the observations of the 7,14 and 28 day unconfined compressive strength results.

A similar trend was observed with the CBR results shown in Figure 5, which exhibited a peak CBR value of $7 \%$ at $10 \%$ CBP content. This peak CBR value is lower than the minimum CBR value of $40 \%$ prescribe for use of material for sub base of lightly trafficked roads (Nigerian General Specifications, 1997).

Durability test results showed that the CBP treated BCS does not have resistance to loss of strength, thus less than the acceptable conventional $80 \%$ accepted as minimum resistance to loss of strength by Ola (1974).

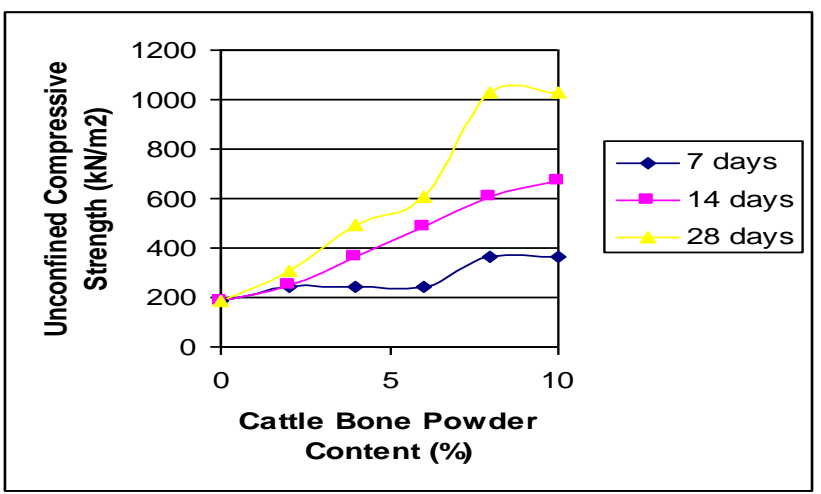

Fig 4: Variation of Unconfined Compressive Strength (UCS) with Cattle Bone Powder (CBP) content.

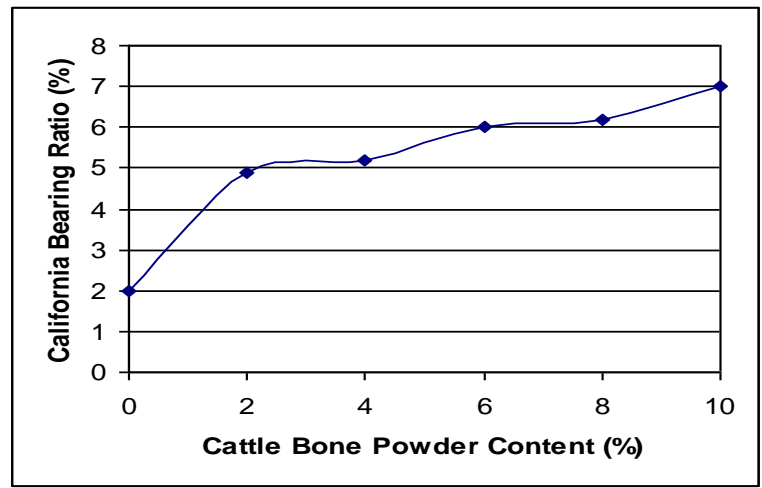

Fig 5: Variation of California Bearing Ratio (CBR) with Cattle Bone Powder (CBP) Content

\section{CONCLUSIONS}

The following conclusions can be drawn from the results of this study.

BCS is an A-7-6 soil using the AASHTO classification system and CL by the USCS. The results presented in this paper have confirmed that the addition of CBP to BCS affects its geotechnical properties; the liquid limit, plastic limit, plasticity index, the UCS and CBR. 
The maximum $10 \%$ CBP content yielded the peak improvement in the geotechnical properties of BCS treated CBP. However, the improved geotechnical properties of the BCS treated CBP did not satisfy the combined strength indices evaluation criteria (i.e. CBR, 7 day UCS and durability) for use as sub-base and base materials in road construction.

The use of a higher CBP content greater than $10 \%$ could be more beneficial in stabilizing BCS. Further study on treatment of CBP with stabilizing agents like cement or bitumen need to be explored.

\section{REFERENCES}

Aribisala, J. O. and Bamisaye, J. A. (2006). Viability of Bone Powder (BP) as Partial Replacement for Cement in Concrete. Botswana Journal of Technology, pp. 2226.

ASTM (1992) Annual book of ASTM standard. American Society for Testing and Material, Philadelphia.

BS 1372 (1990). Method of Testing Soils for Civil Engineering Purposes. British Standard Institute, U.K.

BS 1377 (1990). Methods of Tests for Soils for Civil Engineering Purposes Part 2. British Standards Institutes, London.

Carter, J. D., Barber, W. and Tait, E. A. (1963). The Geology of Parts of Adamawa, Bauchi and Bornu Provinces in North-Eastern Nigeria. Geological Survey of Nigeria, Bulletin No. 30, pp. 1 - 99.

Cha, J., Cui, M., Jang, M., Cho, S., Moon, D. and Khim, J (2011). Kinetic and Mechanism Studies of the Adsorption of Lead onto Waste Cow Bone Powder (WCBP) Surfaces. Environmental Geochemistry and Health. Volume 33, Supplement 1, pp. 81-89.

http://en.wikipedia.org., Accessed on $20^{\text {th }}$ May, 2011

Iorliam, A. Y., Agbede, I. O. and Joel, M. (2012). Effect of Cement Kiln Dust on Some Geotechnical Properties of Black Cotton Soil. Electronic Journal of Geotechnical Engineering, Oklahoma State University USA. Vol. 17, Bund. H., pp. 967-977.

Joel, M. and Agbede, I. O. (2008). Lime-Sand Stabilization of Igumale Shale Mixtures for Road Work. Nigerian Journal of Engineering, Faculty of Engineering $A B U$ Zaria. Vol.14. No. 1, pp. 16-22.
KDOT, (2004). Use of Cement Kiln Dust for Subgrade Stabilization, KS-04-3, Kansas. Department of Transportation, Topeka, Kansas, USA.

Kogbe, C. A. (1989). Geology of Nigeria. Rock view (Nigeria) Limited, Jos.

Madjo, E. and Riskowiski, G. (2004). "A Procedure for Processing Mixtures of Soil, Cement, and Sugar Care Bagasse". Agricultural Engineering International. The Journal of Scientific Research and Development. Manuscript BC 990, Vol. III, pp. 1-5.

Medubi, A. (1998). Stabilization of Black Cotton Soil using Superphosphate Fertilizer Processing Residue as Admixture. Unpublished M.Sc. Thesis Department of Civil Engineering, Ahmadu Bello University, Zaria.

Murthy, V. N. S. (2008). Soil Mechanics and Foundation Engineering. CBS Publishers \& Distributors, New Delhi.

NBRRI, (1983). "Engineering Properties of Black Cotton Soil of Nigeria and Related Pavement Design". Nigerian Building and Road Research Institute Research Paper, No.1, p.2.

Nigerian General Specification (1997). General Specification for Bridge and Roads Work. Federal Ministry of Works, Lagos, Nigeria.

Okafor, F. O. and Okonkwo, U. N. (2009). Effects of Rice Husk Ash on Some Geotechnical Properties of Lateritic Soil. Leonardo Electronic Journal of Practices and Technologies, Issue 15, pp. 67-74.

Ola, S. A. (1974) "Need for Estimated Cement Requirements for Stabilization of Laterite Soil." Journal of Transportation. Engineering. Div., ASCE, 100 (2), pp $379-388$.

Oriola, F. and Moses, G. (2010). Groundnut Shell Ash Stabilization of Black Cotton Soil. Electronic Journal of Geotechnical Engineering, Paper 10,036.Oklahoma State University USA. www.ejge.com

Osinubi, K. J. and Eberemu, A. O. (2005). "The Use of Blast Furnace Slag Treated Laterite in Attenuation of Ground Contaminant" Proc. Of the Nigerian Material Congress 2005 (NIMACON). Nov. 17 $7^{\text {th }}-19^{\text {th }} 2005$. Zaria, Nigeria, pp.28-35.

TRRL (1977) "A guide to the structural design of Bitumen surfaced Roads in tropical and Sub - Tropical countries" Transport and Road Research Laboratory, Road Note 31, H. M. S.0. London. 